\title{
Kohti uutta keskustelutilannetta
}

\begin{abstract}
Tervonen, Ilkka. 1981. Kohti uutta keskustelutilannetta. Aikuiskasvatus 1, 1, 26-28. - Artikkelissa tarkastellaan aikuiskasvatuksen/-koulutuksen terminologian, käsitesisältöjen ja toiminnan luonteen ja lähtökohtien muuttumista viimeisen neljännesvuosisadan aikana. Artikkelissa esitetään, ettei julkisen vallan vaikutuksen lisääntyminen aikuiskasvatuksen kehittämistoimintaan ole ollut pelkästään myönteistä. Alan terminologian kehitys viittaa osaltaan myös reaalisiin muutoksiin tieteen, sivistystyön ja valtiollisen koulutuspolitiikan keskinäisissä suhteissa. Sivistystyön käytännöllä nähdään olevan kolme erilaista lähtökohtaa: sivistystyön sisäiset, julkisen vallan ja tieteen lähtökohdat. Nämä lähtökohdat poikkeavat toisistaan ratkaisevasti; ei voi olla tieteellistä aikuiskasvatuspolitiikkaa eikä parlamentaarista aikuiskasvatustiedettä.
\end{abstract}

Aikuiskoulutuskomitea artikuloi ilmeisen hyvin 1970-luvun alkupuolen kasvuoptimistisen vision, koska sen työ ei juuri herättänyt laajempaa keskustelua. Tultaessa viime vuosikymmenen jälkipuoliskolle alkoi kuitenkin ajattelutapa muuttua kaikilla yhteiskunnallisen elämän osa-alueilla. Kysymys ei ole ollut ainoastaan joistain ajattelutavan tarkistuksista, vaan koko se optiikka, jonka kautta lähestymme maailmaa, alkoi muuttua. Muutoksen taustalla on todennäköisesti jatkuvan taloudellisen kasvun perspektiivin murtuminen ja siihen liittyneiden itsestäänselvyyksien problematisoituminen.

Tämä murtuma, jonka kenties näkyvin ilmaus on ollut ns. vaihtoehtoinen liikehdintä, on johtanut nimenomaan vapaan sivistystyön sektorilla myös Aikuiskoulutuskomitean työn uudelleenarviointiin. Keskustelua on osaltaan kiihdyttänyt se, että 1970-luvun lopulla käynnistyneessä julkisen vallan harjoittamassa aikuiskoulutuksen kehittämistyössä on tapahtunut muutos otettu huomioon vain pinnallisesti.

Käyty keskustelu on vapaan sivistystyön osalta kanavoitunut erityisesti Opistolehteen (Kansalais- ja työväenopistojen liiton julkaisu), jossa asiasta on julkaistu kolme perusteellisempaa artikkelia: Jukka Tuomiston artikkeli, jossa hän käsitehistorialliselta kannalta arvostelee aikuiskoulutuksen ottamista yleiskäsitteeksi1; Arvo Ikosen artikkeli, jossa tämä korostaa, ettei vapaata sivistystyötä voida sulkea aikuiskoulutuksen piiriin ${ }^{2}$; Aulis Alasen artikkeli, jossa hän pohtii terminologian suhdetta käsitesisältöihin 3 .

Käydyssä keskustelussa on selvästi ilmennyt, että aikuisten parissa harjoitettavaa sivistyksellistä toimintaa voidaan tarkastella hyvin eri tavoin - ratkaisevaa on, mikä inhimillisen käy- tännön alue on lähtökohtana. Inhimillinen käytäntö, usein puhutaan praksiksesta, jakautuu eri alueisiin: tiede, taide, politiikka jne. Kullakin käytännön alueella on oma rakenteensa ja tähän rakenteeseen liittyvä tavoitteisuuteensa; tästä on puhuttu esimerkiksi rakenneintentionaalisuutena 4 ja tavoiterationaalisuutena 5 .

\section{Mahdolliset "semantiikat",}

Tätä taustaa vasten voidaankin kysyä, mitkä ovat ne inhimillisen käytännön alueet, joista käydyssä keskustelussa on lähdetty. Lähinnä on erotettavissa kolme aluetta:

1. Tiede. Tieteellisen käytännön rakenteellisena tavoitteisuutena on ihannetapauksessa totuus - ainakin sen jossain filosofisessa merkityksessä - jota on mahdollisuus lähestyä vain tieteellisen tutkimuksen ja tieteellisen keskustelun tietä. 6

2. Sivistystyö. Käytännön sivistystyön rakenteeseen ja toimintatapaan liittyvä intentio on ilmeisesti ajatus sivistämisestä ja sivistymisestä ainakin jossain mielessä. ${ }^{7}$

3. Aikuiskoulutuspolitiikka. Aikuiskoulutuspolitiikka on osa julkisen vallan harjoittamaa yhteiskuntapolitiikkaa, joka nousee valtiollisen hallinnan sisäisistä tarpeista.

Näillä kullakin alueella on oma "semantiikkansa", joka ratkaisee sen, miten käsitteiden merkityssisällöt muodostuvat. Historiallisesti lähtökohtana on käyttämämme luonnollinen kieli, jossa symbolit ja merkitykset ovat kytkeytyneet toisiinsa välittömän arkitodellisuuden edellytyksillä. Tiede on jo varsin erikoistunut inhimillisen käytännön alue, jossa symbo- 
lit saavat viime kädessä merkityksensä suhteessa teoriaan. 8 Sivistystyön käytännön alueella taas merkitysten muotoutuminen on liittynyt tämän käytännön asettamiin tehtäviin, ongelmiin ja ajatuksiin. Julkinen hallinto puolestaan on harjoittanut "käsitetuotantoa" yhä uusilla elämänalueilla; yhteistä näille kaikille alueille kuitenkin on, että näin tuotetun terminologian merkitykset ovat muodostuneet suhteessa valtiohallinnon ajattelu- ja toimintatapaan.

Näin voimme siis erottaa useampia mahdollisia "semantiikoita" tai täsmällisemmin: mahdollisten maailmojen semantiikoita9. Kun edelleen tarkastellaan, miten eri käytännön alueilla muodostuneet merkitykset muuttuvat, saadaan vielä täsmällisempi kuva niiden erilaisuudesta. Luonnollisten kielten piirissä ei merkityksiä voida muuttaa "keinotekoisesti", esimerkiksi päätöksin tai sopimuksin. Merkitykset muuttuvat vain historiallisten olosuhteiden ja siihen liittyvän arkitodellisuuden muuttuessa. Erityisesti luonnollisten kielten vanhempien kerrostumien osalta on kysymys hyvin hitaista prosesseista.

Tässä suhteessa esimerkiksi tieteen kieli on erilaista: sen piirissä uudet merkitykset syntyvät teorioitten muuttuessa. Sivistystyössä taas vastaavaa uudistumista tapahtuu käytännön uudistuessa. Sen sijaan julkisen vallan piirissä merkitystä koskevat ongelmat ratkeavat hallinnollisen konsensuksen tietä tai vaikkapa parlamentaarisella enemmistöpäätöksellä. Kuvaavaa on, miten Aikuiskoulutuskomitea antoi äänestyspäätöksellä aikuiskoulutuksen käsitteelle uuden merkityssisällön. Tämä ei olisi mahdollista sen paremmin tieteen kuin sivistystyön käytännönkään piirissä - puhumattakaan luonnollisista kielistä.

\section{Kansansivistyksestä aikuiskoulutukseen}

On selvää, että edellä luonnehditut mahdolliset "semantiikat"' eivät ole puhtaita; ne eivät voi olla sitä edes teoriassa. Sitä paitsi tarkastellut osa-alueet ovat historiallisesti kehittyneet osin toisiinsa liittyen, joskin niiden keskinäissuhteet ovat kokeneet selviä muutoksia. Yksinkertaistaen voidaan erottaa kolme päävaihetta, jotka ovat heijastuneet myös terminologiassa:

1. Kansansivistyksen vaihe. Perinteinen ajatus kansansivistyksestä hallitsi ilmeisesti pitkään 50-luvulle. Tämä heijastui myös vastaavan yliopistollisen oppiaineen nimessä: kansansivistysoppi.

2. Aikuiskasvatuksen vaihe. Tultaessa 60 -lu- vulle vaihtui kansa aikuisiin ja sivistys kasvatukseen, mikä todennäköisesti kertoo myös toiminnan luonteen muutoksesta. Vastaavasti oppiaineen nimi muuttui kansansivistysopista aikuiskasvatukseksi.

3. Aikuiskoulutuksen vaihe. 70-luvulla siirryttiin sitten puhumaan kasvatuksen sijasta koulutuksesta; näin vajaassa 20 vuodessa siirryttiin kansansivistyksestä aikuiskoulutukseen.

Muutoksen luonteen erittely edellyttäisi perusteellista tutkimusta, mutta jo suhteellisen pinnallisesti tarkastellen tuskin voi päätyä muuhun tulokseen kuin että osa-alueitten keskinäiset suhteet olivat vaihtuneet. Nyt voidaankin kysyä: miltä osa-alueilta kehityksen dynamiikka on missäkin vaiheessa määräytynyt? Esitän asiasta muutamia hypoteettisia ja kenties harrastajamaisiakin huomautuksia.

Ensimmäistä siirtymää kansansivistyksestä aikuiskasvatukseen voitaneen luonnehtia tieteellistymisen vaiheeksi. Suhteellisen pragmaattisen kansansivistysopin kehitys on todennäköisesti seuraillut kiinteästi käytännön kansansivistystyötä ja siihen liittyneitä ihanteita. Teoreettinen viitekehys oli tällöin peräisin ensisijaisesti filosofiasta. Kansansivistysopin "opillinen" luonne alkoi väistyä tieteellisten pyrkimysten tieltä lähinnä tieteiden sisäisen dynamiikan toimiessa moottorina. Nyt on kuitenkin muistettava, että tämä tieteellistyminen tapahtui määrätyssä muodossa, jolle oli tyypillistä - Ahmavaaran terminologiaa käyttäen 10 - metodologinen positivismi: se käsitti tieteellisyyden määrällisenä mitattavuutena ja luonnontieteellisenä eksaktiutena. Näin ollen tieteellistyminen ei suuntautunut vain "opillista", luonnetta vastaan, vaan myös sen mukanaan kantamaa spekulatiivis-filosofista tieteenkäsitystä vastaan.

Toista siirtymää aikuiskasvatuksesta aikuiskoulutukseen on mahdollista tarkastella valtiollistumisen vaiheena. Edellä kuvatussa muodossa tapahtuneen tieteellistymisen kanssa tapahtui samanaikaisesti valtion toiminnan voimakasta laajentumista: valtiollisen säätelyn ulottuessa yhä uusille yhteiskunnallisen elämän alueille syntyi tiedepolitiikka, taidepolitiikka, liikuntapolitiikka, kulttuuripolitiikka jne. Tieteet, joista metodologinen positivismi oli amputoinut pois filosofisen perustan, taipuivat helposti palvelemaan "yhteiskuntapolitiikkaa', jonka muodossa valtio palveli "yleistä etua". Ne eivät kyenneet tilittämään suhdettaan "yleiseen etuun" sisältyviin itsestäänselvyyksiin. Juntusen ja Mehtosen uudelleen käyttöönottaman terminologian kielellä 
sanottuna tieteistä puuttui reflektoiva tekijä, ts. ne eivät kysyneet vallitsevien normien pätevyyttä 11 .

Tiivistäen voidaan siis esittää hypoteesi: Ensimmäinen siirtymä merkitsi, että kehityksen sisäinen dynamiikka siirtyi kansansivistystyön käytännöstä tieteen piiriin. Toinen siirtymä puolestaan merkitsi, että dynamiikan tärkeimmäksi tekijäksi muodostui julkinen valta. $\mathrm{Ky}-$ symys ei siis todellakaan ole pelkästä terminologisesta kehityksestä, vaan tieteen, sivistystyön ja valtiollisen koulutuspolitiikan keskinäissuhteissa on tapahtunut reaalisia muutoksia.

Ilmeisesti viimeksi mainitun siirtymän taitekohdan aikuiskasvatuksen sektorilla muodostaa Aikuiskoulutuskomitean työ, jossa pyrittiin yhdistämään toisaalta tieteen ja toisaalta julkisen vallan lähtökohdat. Tällainen on ilmeisen vaikeata, jopa mahdotonta, sillä tieteen ja julkisen vallan rakenteellinen tavoitteisuus - kuten edellä on todettu - poikkeavat ratkaisevasti toisistaan; ei ole tieteellistä aikuiskoulutuspolitiikkaa eikä parlamentaarista aikuiskasvatustiedettä. Ilmeisesti on tarvittu tuolloin yleisesti vallinneiden yhteiskunnallisten itsestäänselvyyksien murtumista, että on tajuttu tämä seikka.

\section{Keskustelun tasot}

Todennäköisesti edellä luonnosteltu tausta tarjoaa yhden mahdollisuuden jäscntää nyt käytyä keskustelua; muitakin mahdollisuuksia varmasti löytyy. Ainakin yksi olennainen johtopäätös on mahdollista vetää, kun problematiikka projisoidaan valitulle taustalle: ei ole olemassa yhtä ainoata "oikeaa" lähtökohtaa. On joukko erilaisia lähtökohtia, sillä sivistystyön käytännöllä, tieteellä ja julkisella vallalla on kullakin omat lähtökohtansa; tämä on realiteetti.

Pelkistäen ja toistaen voidaan sanoa:

1. Sivistystyön sisäisiä lähtökohtia ei voida siirtää sen paremmin tieteen kuin julkisen vallankaan lähtökohdiksi, koska ne ovat kehittyneen sivistystyön omaehtoista käytäntöä varten.

2. Julkisen vallan lähtökohtiin on mahdotonta ahtaa sivistystyön ja tieteen lähtökohtia, koska tiedettä ja sivistystyötä ei voida harjoittaa hallinnollisesti tai parlamentaarisesti.

3. Tieteen lähtökohtia ei voida siirtää sivistystyön tai julkisen vallan lähtökohdiksi, koska ymmärtääkseni tieteellinen sivistystyön käytäntö tai tieteellinen valtiollinen hallinto ovat mahdottomuus.
Luulen, että suurimmat vaikeudet keskustelussa ovat johtuneet näiden seikkojen unohtumisesta. Tosin tähän unohdukseen ovat johtaneet objektiiviset syyt: se alue, jolla tietyssä vaiheessa on ollut hegemonia, on kuvitellut voivansa sanella koko kehityksen logiikan. Mikä sitten on ongelmallista nykytilanteessa? Mielestäni ongelmallista on se, että 70-luvulla valtikka on siirtynyt julkiselle vallalle, joka näennäisesti tieteestä peräisin olevin argumentein on pyrkinyt saattamaan kaikki sivistyksellisen toiminnan alueet oman sisäisen logiikkansa piiriin. Kun tämä logiikka näyttää vielä yhdistyvän huolestuttavaan tulevaisuuden visioon, on arvostelulle varmasti aihetta. Kuitenkin tieteen, sivistystyön ja julkisen vallan rakenteellisten tavoitteellisuuksien erilaisuuden muistaminen on edellytys sellaiselle rakentavalle arvostelulle, joka johtaisi mielekkääseen keskusteluun ja eri alueiden lähtökohtien parempaan tajuamiseen.

\section{Viitteet:}

1. Jukka Tuomisto: Aikuiskasvatus vai aikuiskoulutus - peruskäsite arvioitava uudelleen. Opistolehti $4 / 80$.

2. Arvo Ikonen: Aikuiskoulutus ja vapaa sivistystyö. Opistolehti 7/80.

3. Aulis Alanen: Aikuiskasvatuksen termeistä ja käsitteistä. Opistolehti 1/81.

4. Tähän piirteeseen on kiinnitetty huomiota esimerkiksi fenomenologisen tradition piirissä. Ks. esim. Lauri Routila: Husserl ja Heidegger. Teoksessa Jaakko Hintikka - Lauri Routila (toim): Filosofian tila ja tulevaisuus. Tapiola 1970. Kyberneettisessä teorianmuodostuksessa samaan asiaan viitataan korostamalla, että systeemin rakenne on osoitus siitä, millaisia suorituksia systeemiltä voidaan perustellusti odottaa. Ks. esim. Norbert Wiener: Ihmisistä, koneista, kielestä, s. 62. Porvoo 1969.

5. Weber käytti tästä ilmausta zweckrational (vs. wertrational). Ks. Max Weber: Wirtschaft und Gesellschaft, s. 45. Tübingen 1956.

6. Vrt. esim. Oiva Ketonen: Se pyörii sittenkin, s. 13-16. Porvoo 1976.

7. Klassisen sivistysajatuksen on kiteyttänyt esimerkiksi Zachris Castrén artikkelissa J.V. Snellman ja kansansivistystoimi. Ajatus IV/30. Teoksessa T.I. Wuorenrinne - Viljo Kosonen (toim): Zachris Castrén - kansansivistäjä ajatustensa valossa, s. 38-50. Helsinki 1950.

8. Ks. luonnollisen kielen ja tieteen kielen suhteesta esimerkiksi Georg Klaus: Semiotik und Erkenntnistheorie, Berlin 1973.

9. Mahdollisten maailmojen semantiikkaa on kehitellyt mm. Jaakko Hintikka teoksessa Models for Modalities. Dordrecht 1969.

10. Yrjö Ahmavaara: Yhteiskuntatieteiden kyberneettinen metodologia. Helsinki 1969.

11. Matti Juntunen - Lauri Mehtonen: Ihmistieteiden filosofiset perusteet. Jyväskylä 1977. 